May 2017, vol. 19, pp. 33-38

doi: $10.1515 /$ rtuect-2017-0003

https://www.degruyter.com/view/j/rtuect

\title{
Market Opportunities for Cellulose Products From Combined Renewable Resources
}

\author{
Lauma ZIHARE ${ }^{1 *}$, Dagnija BLUMBERGA ${ }^{2}$ \\ ${ }^{1,2}$ Institute of Energy Systems and Environment, Riga Technical University, \\ Azenes iela 12/1, Riga, LV-1048, Latvia
}

\begin{abstract}
This study investigates available resources that has not been used or is used with low added value, such as woody crops, forest residues and invasive species possibilities in case of cellulosic products. Main aspect is this study is market outlook, to see if the products can have positive market sales if produced. Resource have been selected by availability and current usage and properties they contain. Products have been chosen the most basic, to see is there possibility to enter an existing cellulose product markets. GE/McKinsey matrix have been used for clear visual decision making. The results show that only two out of seven products has a potential in international market.
\end{abstract}

Keywords - Cellulose; invasive species; forest residues; woody crops; bioeconomy

\section{INTRODUCTION}

Increasingly important issue becomes sustainable use of biomass resources, including forest residues, in behalf of bioeconomy principles [1]. Invasive species, like Solidago canadensis (goldenrod) and Herecleum Sosnowskyi (hogweed) in Latvia is also a valid bioresource that has not been successfully used [2], [3]. The forest sector is one of the cornerstones of the national economy in Latvia as well as Latvian forests are considered to be sustainable [4]. Though there is potential to use forest residues with higher added value than it is done now and there is high potential in abandoned agricultural land use in Latvia for short rotation woody crops as well, like aspen, poplar or birch [5]. The use of plant biomass as feedstock for biomaterial production is relevant in bio-based economy scenario of promotion renewable resources [6].

Cellulose is renewable natural biopolymer that is considered to be one of most important organic compounds produced in biosphere. It can be obtained and biosynthesized from plants, wood, see animals, bacteria and fungi [7]-[9]. It has regarded as endless source of feedstock for the increasing demand for biocompatible and environmentally friendly materials and products [8], [10].

Not just cellulosic products are important, but also the antimicrobial quality with help of phenolic compounds that can be obtained in these products, for example paper and packaging [11]. That is one of the reason why forest residues need to be combined with invasive species, like $S$. canadensis contains great amount of phenolic compounds and is stated as antimicrobial [12], [13].

The pulping techniques can be categorized as mechanical, thermal, semi chemical or fully chemical. Chemical methods include Kraft, sulphite, soda and organosolv pulping processes. But one of the chemical applications for wood and non-wood materials which have not yet been fully commercialised is biopulping [14]. Biopulping involves the use of white rot fungi and improves the pulp quality reducing the necessary amount of chemicals for bleaching [14]-[17].

* Corresponding author.

E-mail address: lauma.zihare@rtu.lv 


\section{Methodology}

Methodology algorithm, see Fig. 1, firstly is based on the resource and how to use it not only from environmental point of view, but economic as well. The most evaluated aspect in economic here is market sales. When resource had selected, the most suitable technology had acknowledged and calculations made taken into account market, product, industry, environmental impact data and economic and macro-environmental data. When results had been obtained, they were put into $\mathrm{GE} / \mathrm{McKinsey}$ matrix for decision making. If the product shows positive market opportunities than the resource is stated as valid, if not - other resource or complex needs to have evaluated.

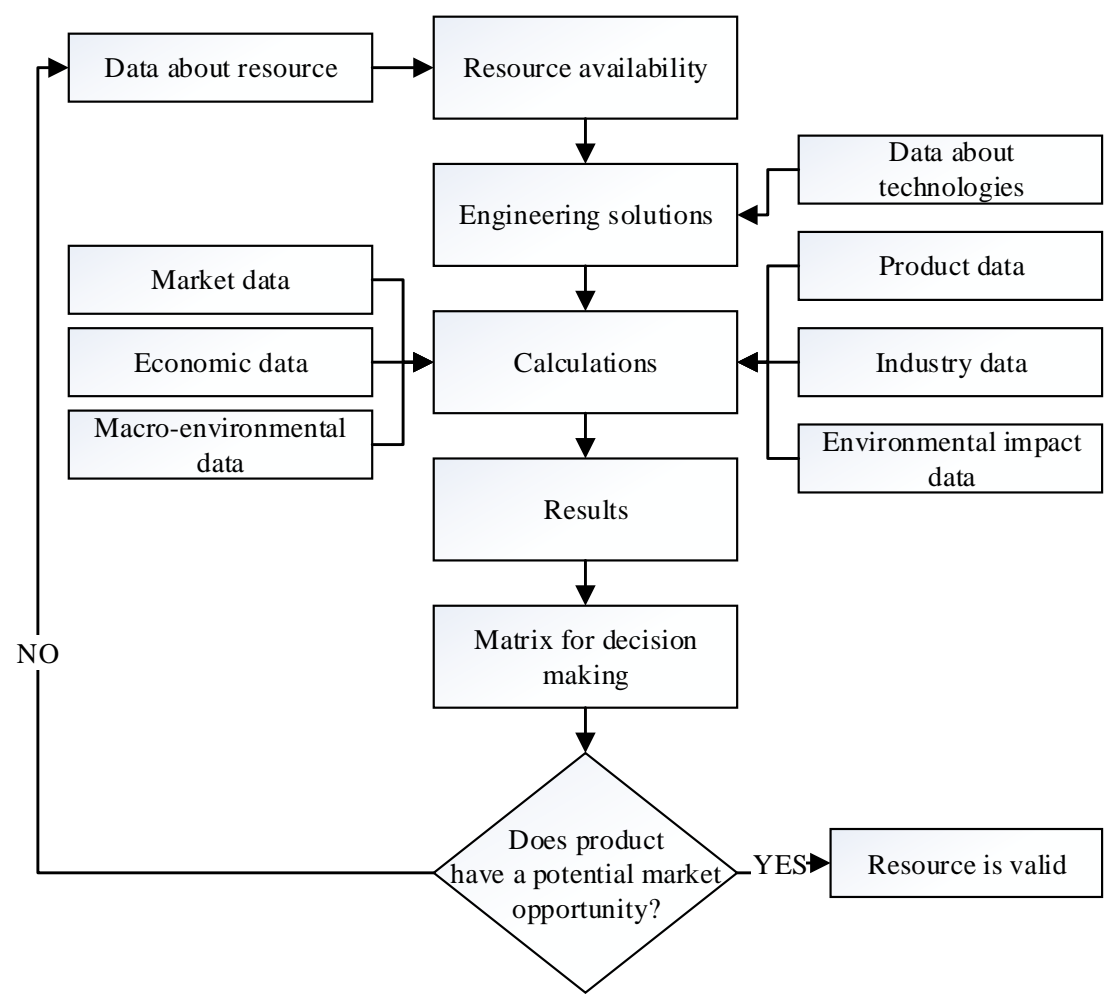

Fig. 1. Methodology algorithm.

Calculations for market attractiveness includes such factors as market size, market potential growth rate, environmental protection regulations, price trend, price sensibility, production rentability, product differentiation, presence of equal competitors, R\&D activities, investments, amount of resource used, health awareness. Calculations for product competitive advantages includes such factors as demand, market size, resource advantages, product price and quality, production costs and flexibility and environmental protection activities in production process. Factors is rated in scale from one to five. Each of the factors selected are weighted by importance and relevance. Total weight ratio is one and is set by experts. Competitive advantages have a set 
of at least two competitor products and final result is relative indicator which is calculated by equation:

$$
R=\left(\frac{B}{B_{\text {comp }}}-1\right) \cdot 100, \%,
$$

where

$R$ - relative indicator of product competitive advantages;

$B$ - new product score estimation;

$B_{\text {comp }}$ - strongest competitor score estimation [18].

General Electric/McKinsey matrix is a great methodology for product portfolio. It is flexible and does not have complex issues [19]. It is widely used for product management and for analysis of competitive scenarios [20].

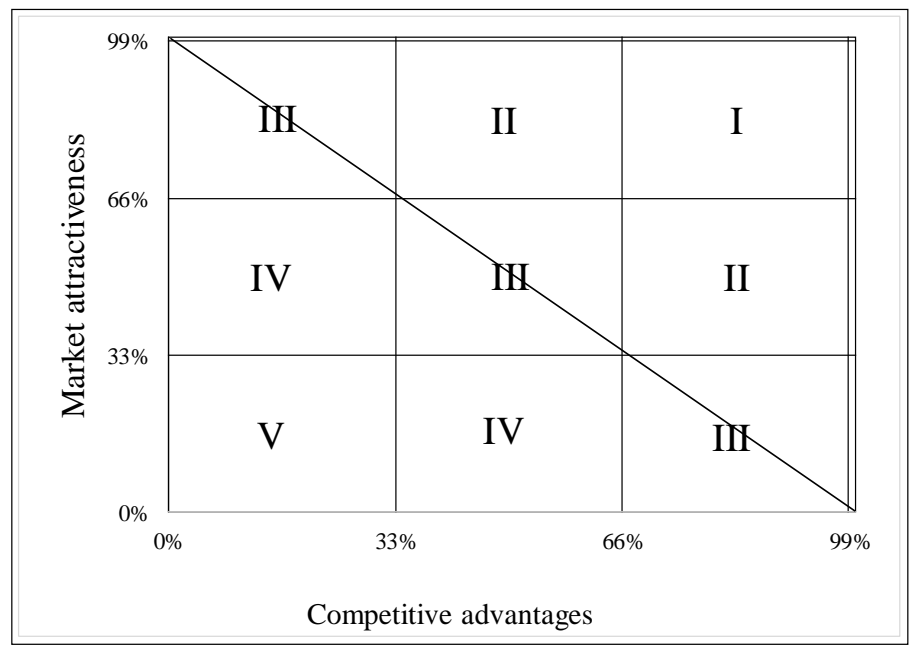

Fig. 2. GE/McKinsey matrix.

The matrix contains nine grid and can be evaluated in two ways - depending on the position of the linear line that connects both axis maximums or based on quadrant where the product takes placement. If product stands above the line, there is potential for commercialisation and if below than it should be improved or discarded. As for quadrants - first quadrant represents the leader product, that can have a safe path in market, second quadrant represents the positive potential and can be invested in, although it can be improved. Third quadrant products are advisable to evaluate and improve before entering the market, but has a steady position. Fourth quadrant represents weak position and is not advisable to invest before evaluation and improvement. Fifth quadrant products have to be discarded without evaluation [19], [21].

Product is represented as circle, where the diameter of circle illustrates the market size of the product. 


\section{RESUlts}

The resource is combination of forest residues and short rotation woody crops together with invasive species - hogweed and goldenrod. The technology acknowledged is chemical method with biopulping pre-treatment. The market is set as international and products are chosen the most basic cellulosic products - paper, packaging, wadding, fluff pulp, film, fibre and textile.

Table 1. Results of Cellulose Product Market AtTRaCtiveness and Competitive ADVANTAGES

\begin{tabular}{lll}
\hline Product & Market attractiveness & Competitive advantages \\
\hline Wadding & $43 \%$ & $33 \%$ \\
Fluff pulp & $64 \%$ & $21 \%$ \\
Textile & $66 \%$ & $55 \%$ \\
Film & $59 \%$ & $18 \%$ \\
Packaging & $49 \%$ & $6 \%$ \\
Paper & $50 \%$ & $4 \%$ \\
Fiber & $76 \%$ & $38 \%$ \\
\hline
\end{tabular}

In Table 1 results are shown for product types and the range is from $43 \%$ to $76 \%$ for market attractiveness and from $4 \%$ to $55 \%$ for competitive advantages. Market attractiveness does not show considerable disparity and results are more average, however competitive advantages are contrary - significant disparity from average to low results.

For better visual and decision making all results have been put in GE/McKinsey matrix as shown in Fig. 3.

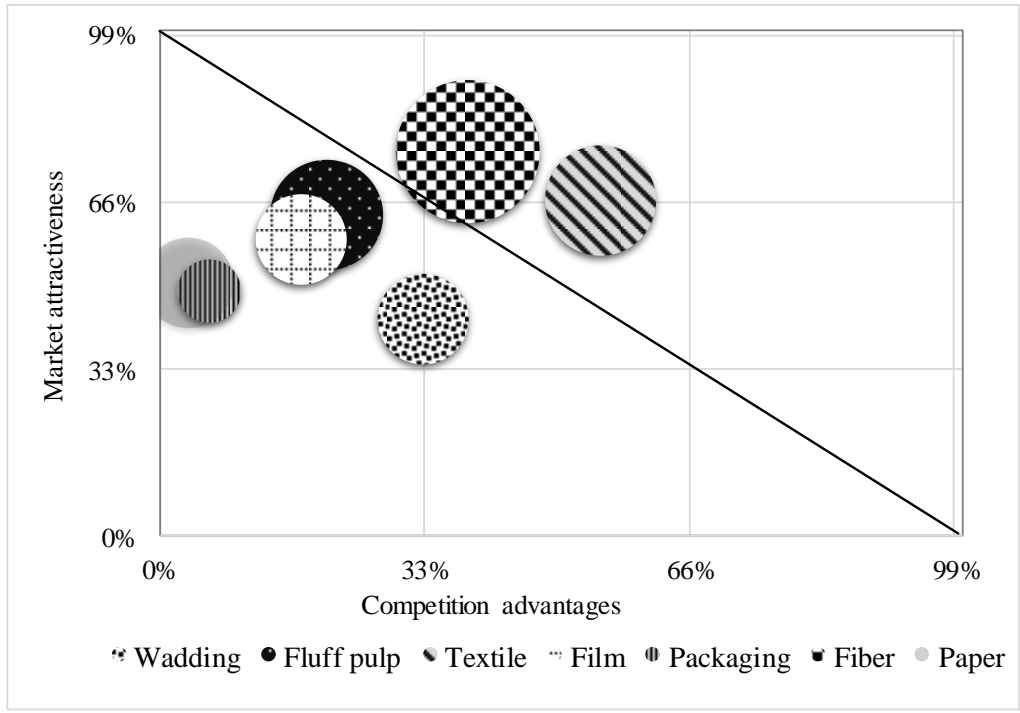

Fig. 3. GE/McKinsey matrix results for cellulose products. 
Results in matrix show that neither product is in leader position nor discarding position. Best results are for fibre and textile, which are relevant - because fibre can be used for different applications one of which is textile therefore market share for textile is smaller. Paper and packaging show major competition and takes the weakest position in market sales, to improve its positions, there should have a major contribution in ability to compete as well as improve the market attractiveness if possible. Fluff pulp takes relatively large market share, it also has good market attractiveness, but the competitive advantages is rather low, if there is a possibility to perform activities to improve this rating, then there could be possibility for commercialization. Film has the similar result as fluff pulp, with smaller market share, but the same possibilities to improve. Wadding has an average market attractiveness and average competition advantages, improving both of these ratios there is a possibility to have a better result.

\section{CONCLUSION}

In this case study the methodology carried through have proved to be a good example to have an insight and first impression about market sales for different basic cellulose products. The GE/McKinsey matrix has a great visual and it can be adapted to different situations and parameters and is a great tool for decision making.

There could be further research in more complicated and innovative product market opportunities where the importance of antimicrobial effect is inevitable.

Although the results showed only two products with great potential in international market, there can be different situation in local market or in concrete market segments.

\section{ACKNOWLEDGEMENT}

The work has been supported by the National Research program "Energy efficient and low-carbon solutions for a secure, sustainable and climate variability reducing energy supply (LATENERGI)".

\section{REFERENCES}

[1] Muizniece I., Klavina K., Blumberga D. The Impact of Torrefaction on Coniferous Forest Residue Fuel. Energy Procedia 2016:95:319-23. doi: 10.1016/j.egypro.2016.09.013

[2] Zihare L., Blumberga D. Insight into Bioeconomy. Solidago canadensis as a valid resource. In the proceedings of CONECT 2017. International Scientific Conference of Environmental and Climate Technologies, Riga, Latvia, 2017.

[3] Zihare L., Blumberga D. Invasive species application in Bioeconomy. Case study Heracleum Sosnowskyi Manden in Latvia. Energy Procedia 2017:113;238-243.

[4] NGO Zalas majas. Latvian forest sector in facts 2015 [Online]. Available: http://www.zalasmajas.lv/wpcontent/uploads/2016/02/skaitlifakti LV web.pdf

[5] Abolina E., Luzadis V. A. Abandoned agricultural land and its potential for short rotation woody crops in Latvia. Land Use Policy 2014:49:435-45. doi: 10.1016/j.landusepol.2015.08.022

[6] Guerriero G., Hausman J. F., Strauss J., Ertan H., Siddiqui K. S. Destructuring plant biomass: Focus on fungal and extremophilic cell wall hydrolases. Plant Sci 2015:234:180-93. doi: 10.1016/j.plantsci.2015.02.010

[7] Thakur V. K., Thakur M. K. Processing and characterization of natural cellulose fibers/thermoset polymer composites. Carbohydr Polym 2014:109:102-17. doi: 10.1016/j.carbpol.2014.03.039

[8] Brinchi L., Cotana F., Fortunati E., Kenny J. M. Production of nanocrystalline cellulose from lignocellulosic biomass: Technology and applications. Carbohydr Polym 2013:94:154-69. doi: 10.1016/j.carbpol.2013.01.033

[9] Ummartyotin S., Manuspiya H. A critical review on cellulose: From fundamental to an approach on sensor technology. Renew Sustain Energy Rev 2015:41:402-12. doi: 10.1016/j.rser.2014.08.050 
[10] Siqueira G., Bras J., Dufresne A. Cellulosic Bionanocomposites: A Review of Preparation, Properties and Applications. Polymers (Basel) 2010:2:728-65. doi: 10.3390/polym2040728

[11] Elegir G., Kindl A., Sadocco P., Orlandi M. Development of antimicrobial cellulose packaging through laccasemediated grafting of phenolic compounds. Enzyme Microb Technol 2008:43:84-92. doi: 10.1016/j.enzmictec.2007.10.003

[12] Deng Y., Zhao Y., Padilla-Zakour O., Yang G. Polyphenols, antioxidant and antimicrobial activities of leaf and bark extracts of Solidago canadensis L. Ind Crops Prod 2015:74:803-9. doi: 10.1016/j.indcrop.2015.06.014

[13] Radusiene J., Marska M., Ivanauskas L., Jakstas V., Karpaviciene B. Assessment of phenolic compound accumulation in two widespread goldenrods. Ind Crops Prod 2015:63:158-66. doi: 10.1016/j.indcrop.2014.10.015

[14] Kamoga O. L. M, Byaruhanga J. K., Kirabira J. B. A review on pulp manufacture from non wood plant materials. Int. J. Chem. Eng. Appl. 2013:4:144-8. doi: 10.7763/IJCEA.2013.V4.281

[15] Ferraz A., Guerra A., Mendonça R., Masarin F., Vicentim M. P., Aguiar A., et al. Technological advances and mechanistic basis for fungal biopulping. Enzyme Microb Technol 2008:43:178-85. doi: 10.1016/j.enzmictec.2007.10.002

[16] Yaghoubi K., Pazouki M., Shojaosadati S. A. Variable optimization for biopulping of agricultural residues by Ceriporiopsis subvermispora. Bioresour Technol 2008:99:4321-8. doi: 10.1016/j.biortech.2007.08.043

[17] Fonseca M. I., Farina J. I., Castrillo M. L., Rodriguez M. D., Nunez C. E., Villalba L. L., et al. Biopulping of wood chips with Phlebia brevispora BAFC 633 reduces lignin content and improves pulp quality. Int Biodeterior Biodegrad 2014:90:29-35. doi: 10.1016/j.ibiod.2013.11.018

[18] Muska A. Uznemejdarbibas planosana. Riga: 2005.

[19] Decuseara N. R. Using The General Electric / Mckinsey Matrix In The Process Of Selecting The Central And East European Markets. Manag Strateg J 2013:19:59-66.

[20] Amatulli C., Caputo T., Guido G. Strategic Analysis through the General Electric/McKinsey Matrix: An Application to the Italian Fashion Industry. Int. J. Bus. Manag. 2011:6:61-75. doi: 10.5539/ijbm.v6n5p61

[21] Shen L., Zhou J., Skitmore M., Xia B. Application of a hybrid Entropy-McKinsey Matrix method in evaluating sustainable urbanization: A China case study. Cities 2015:42:186-94. doi: 10.1016/j.cities.2014.06.006
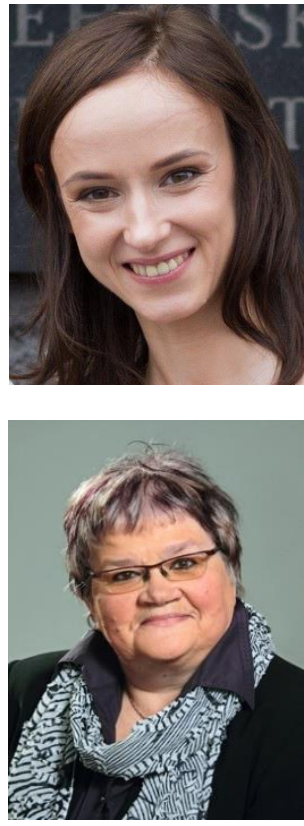

Lauma Zihare, M.sc., Riga Technical University, Institute of Energy Systems and Environment. Lauma Zihare acquired Bachelor's degree of Social sciences in Management in 2011 at University of Latvia and Master's degree in Environmental Science in 2016 at Riga Technical University.

She has continuous working experience as s Researcher in Riga Technical University. Currently she is a PhD student at Institute of Energy Systems and Environment. The main research area is invasive species application in bioeconomy.

Dagnija Blumberga, Dr.habil.sc.ing., professor, director of the Institute of Energy Systems and Environment, Riga Technical University. She has two steps doctoral degree "Condensing Unit" was defended in Lithuanian Energy Institute, Kaunas (1988). Doctor Habilitus Thesis "Analysis of Energy Efficiency from Environmental, Economical and Management Aspects" was prepared in Royal Institute of Technology (KTH) Stockholm (1995) and was defended in Riga Technical University (1996).

Dagnija Blumberga has been part of academic staff of, Riga Technical University since 1976 and director of Institute of Environmental Protection and Energy Systems since 1999.

The main research area is renewable energy resources. She has participated in different local and international projects related to energy and environment as well as are author of more than 200 publications and 14 books. 